\title{
THE WRONG PRACTICE OF ANOINTING OIL IN THE CHURCH ACCORDING TO JAMES 5:14 A THEOLOGICAL STUDY
}

\author{
Sayangi Laia ${ }^{1)}$ Harman Ziduhu Laia ${ }^{2)}$ Daniel Ari Wibowo ${ }^{3)}$ \\ 1) Evangelical Theological Seminary of Indonesia - Surabaya \\ E-mail: Sayangilaia561@gmail.com \\ 2) Evangelical Theological Seminary of Indonesia - Surabaya \\ E-mail:laiaharman@gmail.com \\ 2) Evangelical Theological Seminary of Indonesia - Surabaya \\ E-mail: ariwibowodaniel9@gmail.com
}

\begin{abstract}
The practice of anointing with oil has been done in the church since the first century to the present. On the other hand, there are also churches which have refused to do this. The practice of anointing with oil has essentially lifted from James 5:14. This text has become one of one text in the New Testament which is quite difficult to understand and bring a variety of views. Not a few denominations of the church understand James 5:14 is wrong, even the Catholic church including in it. The increasingly incorrect practice of anointing in the church today, that can be believed can heal disease physically and a variety of other functions push back the author to check the text of James 5:14 in the exegesis. Studies the exegesis of the deep, which focuses on the contextual, grammatical-structural,
\end{abstract}

Keywords: Oil the anointing, the Healing, the Sick, the Church, and James ..

\section{INTRODUCTION}

The practice of anointing with oil as the medium has been practiced in many churches with different meanings and purposes. For example, ordaining God's servants in the church, sprinkling houses or other things, and finally anointing the sick so that they can receive healing. This last use will be the focus of the study in this paper.

\footnotetext{
1 "Catechism Kopendium of the Catholic Church" translated from "Catechismo della Chiesa Cattolica" by Harry Susanto, Sj, (Yogyakarta: Kanasius, 2013), 109-110.
}

The Catholic Church includes the anointing of the sick as one of the seven sacraments which this church claims to have instituted by Christ Himself and affirmed by Saint James. ${ }^{1}$ This church further understands that this sacrament provides comfort, peace, courage, and even forgiveness of sins if the sick person cannot confess his sin (cannot be healed. ${ }^{2}$ ). Even if God willed this sacrament is aimed at

\footnotetext{
${ }^{2}$ Albertus Sujoko, MSC, The Practice of the Sacrament of Repentance in the Catholic Church: Historical, Dogmatic, and Pastoral Overview, (Yogyakarta: Kanasius, 2008), 153.
} 
preparing the sick person for the journey to the House of the Father. ${ }^{3}$

Sacraments in the Armenian church are similar to the Catholic church, are referred to as "extreme unction" and only lasted until the 14th century AD due to the emergence of a heresy that equated the sacrament of unction with the sacrament of penance. The oil used is called "holy muron" (murron, meaning myrrh). ${ }^{4}$

The Eastern Assyrian Church generally follows the seven sacraments defined by Mar Abdison. ${ }^{5}$ The anointing oil is known as Qarna oil, holy horn oil, or anointing oil. This church believes that this oil comes from the apostles, so it is called the oil of the apostles. They believed that if the apostles' oil was low, it was added. They believed that the added oil had the same blessings as the original oil of the apostles. ${ }^{6}$ For this church, the anointing of the sick is a sign and also has the effect of the forgiveness of sins and the healing

\footnotetext{
3 "Catechism Copendium of the Catholic Church", 110.

${ }^{4}$ Colin Macfarquhar and Andrew Bell, The Encyclopedia Britannica a Dictionary of Arts, Sciences, and General Litterature: VI, (Scotland: Charles Black, 1974), 139, 554.

${ }^{5}$ William Toma, "The Mystery of the Church. Syriac Critical Edition and Translation of the Rite of the Consecration of the Altar with Oil and the Chapter 'On the Consecration of the Church' from the 'Book of the Seven Causes of the Mysteries of the Church' "from Patriarch Timothy II's Doctoral Dissertation ( 1318-1332) at the Eastern Papal Institutions in Rome (Rome, 2007). At the Holy Synod meeting in 2001, the Assyrian Church in the East officially adopted the seven sacraments as
}

power of Christ. The sign which means the healing of the sick person by the anointing is a sign for him to enter the kingdom of God. $^{7}$

The Eastern Orthodox Church holds an anointing ceremony with oil (euchelaion). ${ }^{8}$ Dr. King explained that although the Greek church considers (the anointing of the sick) a mystery, it is certain that no one church gave it only to people "perieulosa aegrotantibus et mortis perieulo imminente" (and those who were in danger of death / dying), as was done in the Roman church. On the other hand, anointing can be used in any disease as holy and generous work, but it is done not out of necessity, and so the medical in the church is of the opinion that this anointing is neither obligatory nor applicable to everyone. ${ }^{9}$

In the Reformed church, the practice of anointing the sick was not practiced in the

\footnotetext{
listed by Mar Abdisho of Nisibis.

${ }^{6}$ Charles Herbermann, Catholic Encyclopedia East Syrian Rite, (New York: Robert Appleton Company, 1913), accessed at http://www.newadvent.org/cathen/14413a.htm on February 27, 2020.

${ }^{7}$ Jeffrey Gross, FSC, et al, Introduction to Ecumenism, (New York: Paulist Press, 1938), 97.

${ }^{8}$ Douglas A. Moo, "Tyndale New Testament Commentaries: James", the word "eucelaion" comes from the words "euche" meaning "prayer" and "elaion" meaning "oil", 176-177.

${ }^{9}$ Joseph B. Mayor, The Epistle of St. James: The Greek Text With Introduction Notes and Comments - Edition II, (London: Macmillan \& CO, 1897), 167.
} 
Lutheran church. ${ }^{10}$ This is due to Luther, who was the Lutheran father to believe in only two sacraments which are biblical, in the sense that Christ established directly, namely baptism and the Lord's Supper. The other five sacraments that Roman Catholics believe are rejected. ${ }^{11}$

The Anglican Church in its 1552 and subsequent editions of the book "Book of Common Prayer" eliminated the practice of anointing that existed in the original 1649 version of the order on visits to the sick. Later their church's 20th century prayer book contained the practice of anointing the sick. ${ }^{12}$ In the "Thirty-Nine Articles" as the church teaching norm, in article 25 the Anglican church receives two sacraments of the gospel (ordained by Christ, namely baptism and eucharism, while the other five sacraments (confirmation, penance, commandment, marriage, estrem anointing) are not included in the sacrament of the gospel, but its nature is permitted. ${ }^{13}$ The practice of anointing was included in the

\footnotetext{
10 "Lutheran Service Book: Pastoral Care Company" written by "The Commison on Worship of The Lutheran Church-Missouri Synod", (Missouri: Concordia Publishing House, 2007), 34. ${ }^{11}$ Dr. Jan S. Aritonang, Various Sects in and Around the Church, (Jakarta: BPk Gunung Mulia, 2008), 44-45.

${ }^{12}$ Elizabeth A. Livingstone, The Oxford Dictionary of the Christian Church - Unction, (United States: Oxford University Press, 2005), 1656.

${ }^{13}$ Rev. George Bird, Hints For The Revival of Scriptural Principles, (London: Whittaker and Company, 1842), 47.
}

"care for the sick" ministry in the episcopal church. ${ }^{14}$ This church believes that the anointing is a channel or tool of God's love to provide healing for the spirit, mind, and body. ${ }^{15}$

In general, Protestant churches only receive two sacraments like the Lutheran churches, namely the sacrament of baptism and holy communion (communion). According to the Protestant church, the two sacraments are sacraments directly instituted by the Lord Jesus, while the other five sacraments that the Catholic church believe are sacraments made by humans, which are not written down in the New Testament. ${ }^{16}$ Until now this church has rejected anointing the sick as anointing. ${ }^{17}$

The Pentecostal Church understood oil as a "symbol of the Holy Spirit". ${ }^{18}$ Healing services in Pentecostal and Charismatic churches also come from James 5: 14-15. The nature of this service is:(1) healing services are carried out in special congregational meetings; (2) the

\footnotetext{
14 “The Book of Common Prayer", (New York: Church Publishing Incorporated, 1979), 861.

15 Ibid, 861.

${ }^{16}$ Bassey B. Essien, How To Let Christ Be Formed In You, (Bloomington IN, United: Xlibris Corporation, 2011), 74

17 Walter A. Elwell, Evangilical Dictionary of Theology, (Grand Rapids: Baker Academic, 2011), 130.

${ }^{18}$ Guy P. Duffield, et al, Foundations of Pentecostal Theology, (Los Angeles: Foursquare Media, 1983), 401.
} 
prayer of the elders "the prayer of faith" is a divinely appointed instrument for the healing or restoration of a sick person, either oil or one's own faith. ${ }^{19}$ Thus, Pentecostals / Charismatics emphasize "the prayer of faith" and "oil" in one's healing. However, in the early 21 st century $\mathrm{AD}$, not a few of the Pentecostal and Charismatic churches were too advanced to interpret the practice of anointing. A prominent Pentecostal church leader in one of the largest congregations in Nigeria has written a book entitled "The Mystery of the Anointing Oil". In this book it emphasizes that the anointing oil is the Spirit of God, packaged in a bottle, mysteriously designed to communicate the physical power of God. It is the power of God, it is a versatile medicine for all the ills of life. It is God's power to destroy all of life's inconveniences. It is God's standard against every enemy invasion. It is a mysterious policy bearer. ${ }^{20}$

\section{RESEARCH METHODS}

In discussing the text of James 5:14, of course the author uses the hermeneutic method, namely the exegetical method,

\footnotetext{
${ }^{19}$ WR Downing, Prayer and Anointing with Oil An Examination of James 5: 13-15, (Morgan Hill: PIRS Publication, 2012), 11.

${ }^{20}$ John Wimber and Kevin Springer, Power Evangelism, (San Francisco: Harper and Row Publishers, 1986), 159, 166.

${ }^{21}$ Kevin J. Conner and Ken Malmin, Hermeneutics

- A Textbook on How to Interpret the Bible,
}

which only focuses on contextual, grammatical-structural, and historical analysis.

The word "context" comes from two Latin words "con" means "together" and "textus" means "intertwined". So context means something that is woven together. In literature, the word refers to the thought relationships that exist in part or all of a writing. When applied to the Bible, context means the connection of thoughts which can exist throughout the Bible, or in any one of the Scriptures, or in one of the books of the Bible, or in a particular part of the Bible. ${ }^{21}$ Saparman, $\quad$ STM, classifies contextual analysis as near context and far context. Close context consists of two to three paragraphs before and after the text studied. Whereas remote context consists of all the books (books) that are studied. And it can also refer to the entire Bible. ${ }^{22}$ The old adage says "a text that is out of context is a statement without evidence". ${ }^{23}$

The word "grammatical" relates to grammar. ${ }^{24}$ So grammatical analysis when applied to the Bible is an investigation of

\footnotetext{
(Malang: Gandum Mas, 2004), 105.

${ }^{22}$ Saparman, STM, Bible Study - Methods and

Examples, (Yogyakarta: STII Press, 2007), 102.

${ }^{23}$ Kevin J. Conner and Ken Malmin, 108.

${ }^{24}$ I. Markus Willy PS Pd et al, Indonesian English Dictionary, (Surabaya: Arkola Surabaya, 1996), 142.
} 
grammar in every biblical text, such as investigating the function, number, time (time), mode, voice, and type (gender) of words. The word "structure" is also referred to as "part relationship" ${ }^{25}$ Structural analysis investigates the relationships between paragraphs and sentences (coupling particles) and within paragraphs or sentences (types of words). Each element of a sentence - words, phrases, and clauses has a unique role to play. Furthermore, each sentence in the paragraph has a special role too. Analyzing paragraphs means analyzing sentences. Analyzing a sentence means investigating and understanding every element of it. ${ }^{26}$

Historical analysis (history) serves to investigate the meaning of the language used by the original author and the development of its meaning throughout the history, place and time the book was written. Also serves to investigate facts about the author of the book, the background of the author, the experiences or events that prompted the book to be written, and the main characters in the book. The goal is to place oneself in the author's time and situation so that he can feel together

\footnotetext{
${ }^{25}$ Roy B. Zuck, Basic Interpretation, (USA: David C. Cook, 1991), 135.

${ }^{26}$ John D. Grassmick, Principles and Practice of Greek Exegesis, (Yogyakarta: STTII), 67.

${ }^{27}$ Alan D. Cox, Hermeneutic Principles, Bible Word V4.
}

with him, ${ }^{27}$ it means that the interpreter must view a text based on the state of the text being written, both in the condition of the original author and the condition of the first reader of the text. Walter A Henrichsen said "because the Scriptures come from a historical context, the Bible can only be understood from the point of view of biblical history," 28

\section{RESULTS AND DISCUSSION}

The results and discussion of the text of James 5:14 will be published in writing based on each of the analyzes mentioned above.

\section{Contextual Analysis}

First, in James 5: 13-18 in the Greek text there is seven times the word "prayer", four times in the sense of "proseuchomai" $(13,14,17,18)$, twice in the meaning of "euche" $(15,16)$, and once in the sense of "deesis" (16). The term "proseuchomai" is the technical term in religion for speaking to God to ask / ask His help, usually in the form of supplications, vows, and prayers. This word is usually translated "pray to (pros)". ${ }^{29}$ The word "euche" is used of a special kind of prayer, which is a solemn

\footnotetext{
${ }^{28}$ Walter A Henrichsen, Understand - A Straightforward Approach to Interpreting the Bible, (USA: NAVPRESS, 1976), 81.

${ }^{29}$ Timothy Friberg, et al, Analytical lexicon of the Greek New Testament, (Grand Rapids: Baker
} 
request to ask for something specific. ${ }^{30}$ The word "deesis" mainly means "desire, need", so in the New Testament it is always translated "petition". ${ }^{31}$ The use of the word "prayer" several times in this section shows that James's emphasis in 5: 13-18 is prayer, not anointing. Burdick said "Prayer is the most important of the two services performed by these elders ....... Moreover, the emphasis of the entire paragraph is on prayer. So the anointing is a secondary act. ${ }^{32}$

Second, in James 5: 14-18 there are two times the word "sick", namely in verse 14 it uses the word "asthenei" from the root word "astheneo"; and in verse 15 uses the word "kamnonta" from the root word "kamno". The word "astheneo" from "a" (negative - no) and "stenos", means "strength", then literally the word "astheneo" means "not having strength", "helplessness", "weak, becoming weak", or "sick". Interestingly, the sick person "astheneo" in verse 14 is referred to as the sick person "kamnonta" in verse 15, it means the sick person "astheneo" and "kamnonta" refers to one and the same person. The word "kamnonta" appears only

Books - Baker's Greek New Testament Library, 2000); The meaning of "proseuchomai" (pray to). Bible Works V10.

${ }^{30}$ Mark Dunagan, "Commentary on the Bible James 5:16", accessed at https://www.studylight.org/commentaries/dun/jame s-5.html on May 17, 2020.

${ }^{31}$ WE Vine, Vine's Complete Wxpository twice in the New Testament, in James 5:15 and in Hebrews 12: 3. W. E Vine explained that the meaning of the verb "kamno" is "exhaustion of the mind", this idea can also be seen in the Septuagint translation in Job 10: $1 ; 17: 2$ which refers to the weariness of the mind (translated "bitterness of the soul"). ${ }^{33}$ Therefore, the word "kamno" in Hebrews 12: 3 refers to spiritual weakness / spirituality or "weakness of faith", which is translated "tired / weak in the soul" (kamnein te psuche). People who are spiritually weak (faith) in this context do not talk about someone who has fallen into sin, but talk about weak faith due to suffering, for example they are referred to as "people who are discouraged / discouraged". Therefore, although the word "kamno" in James is not explained in detail, from the meaning of the word and its use in other parts of the New Testament, namely in Hebrews 12: 3 it can be concluded that the word "kamno" in James 5:15 refers to "Spiritual weakness (faith)", namely people who are discouraged / discouraged due to pressure / suffering, not "physical weakness (illness)".

Dictionary of Old and New Testament, (London: Thomas Nelson Publishers, 1996), 4495-4496.

${ }^{32}$ Donald W Burdick, "James", in "HebrewsRevelation" Volume 12 of "The Expositor's Bible Commentary 12 Volume"; Edited by Frank E. Gaebelein and JD Douglas, (Grand Rapids: Zondervan Publishing House, 1981), 204.

${ }^{33}$ WE Vine, 5086. 
Another proof that the word "kamnonta" refers to spiritual weakness (faith) is the use of the word "save" in verse 15 which is related to the word "kamnonta". Yakobus said: "And prayer that is born of faith will save the sick (kamnanto)". The word "save" in the entire context of the book of James is always related to "soul or spirit" appearing in $1: 21 ; 4: 12 ; 5: 20$. Therefore, the word "save" in 5:15 must have the same meaning as verse 20 which has to do with "soul or spirit". Therefore, the word "save" in verse 15 speaks of the "restoration of soul / spirit" of the sick person, related because he is in despair (kamnonta) for the suffering he is going through. And this meaning is only appropriate if the word sick "kamnonta" is understood as spiritual weakness (faith). So,

Next thing to consider is the meaning of the word "asthenei" whether this word refers to physical weakness (disease) or refers to spiritual weakness (faith) such as the meaning of the word "kamnonta". There is some evidence why the word "asthenei" should be understood as "spiritual weakness" in the context of James 5:14, namely: (1) the word "save, awaken, forgive, even the word" healed "in verse $16 \mathrm{a}$ is all related to the word" kamnonta. "(Spiritual weakness / faith). And as has been explained that the word "save, awaken, and forgive" in this context has to do with spirit and soul, not physical. Therefore, the recovery experienced by the sick person is related to spiritual and mental problems, not physical; (2) The use of the word "asthenei" which is not closed may refer to spiritual weakness (faith); (3) it is logical and appropriate to call the elders if the "weakness / illness" referred to in this section is spiritual weakness (faith) rather than physical weakness / illness. Because theologically the elders (church leaders) are responsible for the soul / spirituality of the congregation (Hebrews 13: 7).

Third, James 5:14 implies the pastoral duty of the elders of the church. Therefore, it is logical to understand that the main task of the elders in this section is to "pray for" the sick / weak church, not to "anoint". Praying for the congregation who is "spiritually weak / faith" is stated by the church leaders in other parts of the Bible. This is called a part of pastoral ministry (Acts 20:28), whereas "anointing" is not found anywhere else in the Bible especially the New Testament that deals with pastoral ministry. 


\section{Grammatical-Structural Analysis}

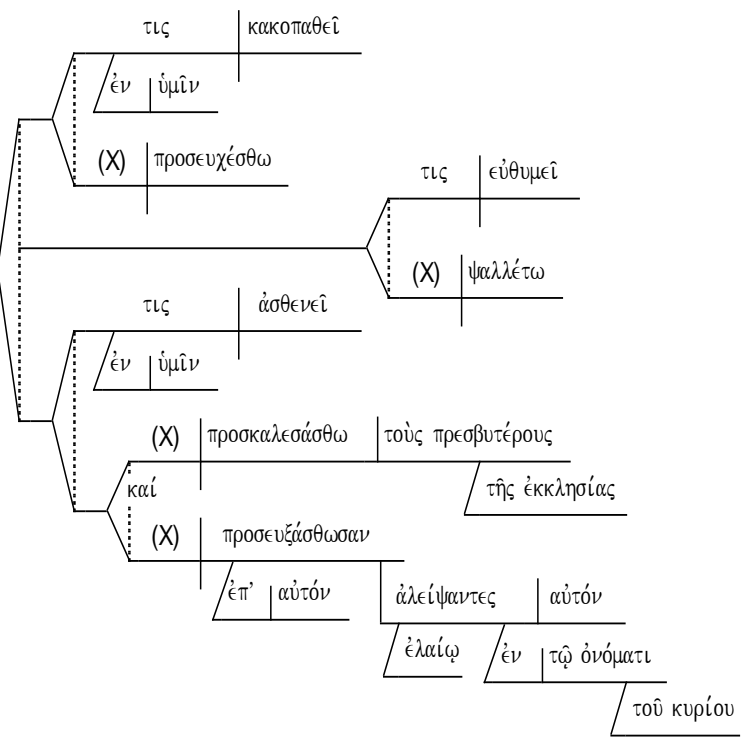

The structure of verses 13-14 above can be understood as follows:

I. Whoever (Person) Suffers (v. 13a)

Action To Do: Pray (Proseuchestho)

II. Whoever (Person) is Happy (v. 13b)

Action To Do: Sing (Phalleto)

III. Whoever (Person) is Sick (v. 14)

A. Actions to be done:

1. Call it
a. Subject: The Sick
b. Direct
Object:
Congregational Elders

2. Pray
a. Subject: Congregational Elders

b. Direct Object: The Sick

B. Actions that are not mandatory

1. Anoint with Oil

\footnotetext{
${ }^{34}$ Compare with the translation of Moulton et al., Vocabulary of the Greek New Testament (VGNT), (London: Hodder and Stoughton, 1924-1930), 548.
}

a. Subject: Congregation Elders

First, the command word "to call" in James 5:14 "proskalesasthoo", that is, the command word aorist midel third person singular, can be translated "he calls to himself", ${ }^{34}$ that is, James commanded the sick man to call himself elders. The imperative aorist mode is usually used to order an action to be carried out in its entirety, its nature does not focus on the past (time), is not repeated or is not carried out continuously, but only once. ${ }^{35}$ Thus, the use of the kala aorist in the command "proskalesasthoo", indicates that the act of summoning the elders is done only once, without being repeated (continually). This case also applies to the command word "proseuxasthoosan" (they pray) has an aorist imperative mode which indicates that this action is done only once, that is, when the elder comes to the place of the sick person.

Second, the use of the imperative aorist mode of the two commands "proskalesasthoo" (call it) and "proseuxasthoosan" (pray) shows that the two commandments are short commands, without further explanation, for example

\footnotetext{
${ }^{35}$ Daniel B.Wallace, The Basics of New Testament Syntax: An Intermediate Greek Grammar, (Grand Rapids: Zondervan Publishing, 2009), 210.
} 
how many elders to call? or how many people should pray for the sick congregation? The issue of text is not about this. So it is not correct to give a stipulation regarding the number of elders to be called and who comes and the number of elders to pray for the sick person. So it can be concluded that the text of the commandment to call and pray for and anoint the sick is not intended as a sacrament (religious ceremony) which has complete ordinances.

Third, in the Greek text in the diagram above appears the word "kai" (and) between the phrase "proskalesastho tous presbuterous tes ekklesias" (he calls him the elders of the church) with the phrase "proseuxastthosan ep 'auton" (they pray over it). The use of the word "kai" indicates that the commands "call" and "pray" are parallel main commands. Meanwhile, the verb "aleiphantes" (anoint) either grammatically or structurally (diagram) is not the main verb parallel to the commands "call" and "pray". Because in a diagrammatic way, the position of the word "aleiphantes" (anoint) is under the command word "proseuxásthoosan" (pray). So, the important action in the context of James 5:14 is "call" and "pray", not "anoint".

Fourth, the word "aleiphantes" can be translated "anoint, grease, rub, pour, grease, and

\footnotetext{
${ }^{36}$ WE Vine, Vine's Complete Wxpository Dictionary of Old and New Testament, (London: Thomas Nelson Publishers, 1996), 142-1424. ${ }^{37}$ Dale M. Wheeler, "Wheeler's Greek Syntax Notes"; Study of the Use of Participant Verbs. PC Bible Study V5.
}

put". There are two main words used in the Bible for "anointing", namely "aleipho" and "chrio". In general, the word aleipho is used for things that are practical in nature, while the word "chrio" is used for things that are religious (sacred). ${ }^{36}$ So the anointing referred to in James 5:14 is not religious anointing (sacramental chrio), but rather practical anointing (aleipho). The verb "aleiphantes" (anoint), that is, the participant verb aorist, and because the main verb "proseuxásthoosan" (pray) is also an aorist, indicating that the time of the anointing (contemporary) with the time of "praying", ${ }^{37}$ it means that the anointing is performed at the time of prayer. So the translation "proseuxastthosan ep 'auton aleiphantes auton" is translated "they pray over it while / while anointing it". The word "aleiphantes" is a participatory mode, not imperative, indicating that the act of anointing is not something that must be done, while what is obligatory is "praying" (imperative mode). When the aorist "aleiphantes" (anoint) indicates that the action was only once, it is not indicating that the action has passed. It is clear that the context that performs this "anointing" is the elders (presbuterous).

Fourth, the word "elaion" in James can be translated "oil" as well as "olive oil" (Luke 7:46; Matt. 25: 3). ${ }^{38}$ There are several 
important things about the study of the word "oil", namely: (1) oil is only a means of anointing, not a means of healing. The nonobligatory nature of the verb "anoint" confirms that the use of "oil" was not for a healing purpose; (2) oil is only a means of anointing, affirming that oil is not a source of healing. Healing does not come from oil, but from God; (3) supposing "oil" is considered a means of healing physical ailments as some people believe, the designation of oil as a means, confirms that oil is not the only healing tool that God uses (cf. John 6: 2; Matt. 8:17 quotes Isa. 5: 4); (4) Grammatically, the purpose for using the oil in James 5:14 is not stated. Then a more precise question regarding the text of James 5: 14 is "why did James ask the elders to anoint the sick one? not "why does the anointing use oil?"; (5) administrators of the anointing are elders. If the oil is meant for healing physical ailments, the elders do not have to perform the anointing. The sick or someone else can do it on their own; (6) if the oil is meant for healing physical ailments, the problem is that oil cannot cure

Word Translation" of the Bible notes on James 5:14. The word "oil" is translated as "olive oil". The "Complete Jewish Bible (CJB)" translation of the Bible translates the word "oil" in James as "olive oil".

${ }^{39}$ EJ Forrester, “An Exegesis of James 5: 14-20”, 215.

${ }^{40}$ Joseph B. Mayor, The Epistle of St. James the Greek Text With Introduction Notes And all kinds of existing ailments. EJ Forrester said: "Why be anointed with oil? It is difficult to say that the oil was used for medicinal purposes. It is true that in James's day oil was often used for medicine. However, oil is not the only medicine nor is it a cure for all diseases ".39

\section{Historical Analysis}

First, James, the Lord's brother is the author of the letter of James (1: 1). ${ }^{40} \mathrm{He}$ was a Jew, therefore, it is important to see the meaning of "anointing" (James 5:14) based on his Jewish background, ${ }^{41}$ for of course James wrote his letter in his Jewish background. This is evidenced by the content of the letter itself in which it alludes to more than twenty books in the Old Testament. He referred to several characters in the Old Testament such as Abraham, Rahab, Job, and Elijah as well as the ten commandments and the law of Moses. ${ }^{42}$

Second, the recipients (readers) of James' letter were Jewish believers living overseas, that is, outside Palestine (Jas. 1:

Comments (Second Edition), (London: Macmillan and Co., 1879), iv.

${ }^{41}$ Robert J. Morgan entitled "James 5:14: Should Anoint the Sick With Oil?"

https://www.robertjmorgan.com/uncategorized/jam es-514-should-we-anoint-the-sick-with-oil/ accessed on 15 May 2020.

${ }^{42}$ Dr. Thomas Constable, Notes on James, (2007 Edition pdf), 2. 
1). James 2: 1, James calls them "people who have faith in Jesus Christ", this shows that they are not only Jews, but Jews who have believed in Christ. They can be called Judeo-Christian. ${ }^{43}$

Since the writer and reader of the letter of James is Jewish, it is certain that the text of James 5:14 must be understood in light of a Jewish background, particularly regarding "the anointing". In Jewish culture, the anointing (aleipho) could have both practical and symbolic meanings. It has been emphasized in the contextual analysis that the anointing referred to by James was not aimed at practically healing a disease physically, since the condition experienced by the sick person was spiritual weakness, not physical. Clearly, then, the "anointing" that James encourages must be understood in a symbolic sense. There are several symbolic meanings of "anointing" in Jewish culture, namely: (1) signs (symbols) of sanctification and inauguration, for example the anointing of kings, prophets, priests, temple instruments, and other objects consecrated to God; (2) sign (symbol) of hospitality and honor to guests; (3) as a

\footnotetext{
${ }^{43}$ Dallas Seminar Faculty, "The Bible Knowledge Commentary New Testament: An Exposition of the Scriptures"; Edited by John F. Walvoord and Roy B. Zuck. Commentary on the book of James by J. Ronald Blue, (USA: David C. Cook, 1985), 816.

${ }^{44}$ WE Vine, 1423-1424.

${ }^{45}$ Douglas J. Moo, "James: An Introduction and Commentary" in "Tyndale New Testament
}

symbol (symbol) of the Holy Spirit; (4) as a sign (symbol) of someone's joy, happiness, and freshness, which indicates that his suffering (mourning) has ended (2 Sam. 1:20; Matt. 6:17). ${ }^{44}$ Of the four "symbolic" meanings of anointing in this Jewish culture, there are only two possible meanings that are appropriate for the anointing in James 5:14, namely: (1) the symbol (sign) is sanctified, meaning that the sick person is sanctified (separated / set apart) for attention. Allah's $\operatorname{special}^{45}(2)$ a symbol (sign) of joy, happiness, or freshness. This means that the anointing received by the sick person represents (a symbol) of the joy, happiness, and freshness received by the sick person because he is weak in faith (spiritual), that is, hopelessness or discouragement due to the stress of the suffering he is experiencing. The anointing shows that the spiritual weakness (faith), that is, that hopelessness or discouragement has ended, now he lives in joy, happiness, and refreshment. ${ }^{46}$

Third, the letter of James was written about $45-48$ C.E. ${ }^{47}$ It can be concluded that the letter of James is the

\footnotetext{
Commentaries Volume 16", (USA: Inter-Varsity Press, 2015), 166-167.

${ }^{46}$ J. Ronald Blue, 834-835.

${ }^{47}$ Donald W. Burdick, et al, "James," in "The Expositor's Bible Commentary (Vol 12) Hebrews through Revelation", (Grand Rapids: Zondervan, 1982), 162.
} 
earliest letter written in the New Testament. ${ }^{48}$ Knowing the date of writing of the letter of James, James 5:14 shows: (1) in the absence of any encouragement to practice anointing in the letters after James, this shows that the practice of anointing in the church is not something important. If that was the case, the New Testament writers after James should at least have advocated it, especially in their pastoral letters; (2) The act of anointing advocated by James 5:14 is still within the scope of Jewish understanding and culture; this is logical because the mailing address is Jewish, not Gentile; (3) In the absence of the encouragement in the letters after James,

Fourth, from 33 to 49 AD James lived in Jerusalem, while his recipients (readers) lived outside Palestine. This indicates that James wrote his letter in Jerusalem. ${ }^{49}$ The main point of determining the place where the letter of James was written is that the anointing recommended by James was still in the context of Jerusalem (Jews) at that time. This again confirms that this anointing must be understood in light of the Jewish culture.

\footnotetext{
${ }^{48}$ J. Ronald Blue, 816; Archibald Thomas Robertson, Word Pictures in the New Testament, (Grand Rapids: Christian Classics Ethereal Library, 1863-1934), 1814

${ }^{49} \mathrm{The}$ argument that James wrote in Jerusalem is explained by IJ Loh and HA Hatton, A Handbook
}

Fifth, the purpose of James in the text of James $5: 14$ is to give appropriate advice (encouragement) for those who are "sick" (spiritually weak), namely to call the elders so that they can pray and anoint them. The main thing that James emphasized was that the sick person should call the elders and they should encourage him, not anoint him. Because the anointing has nothing to do with one's spiritual (faith) matters. Only prayer can help someone in spiritual weakness (faith). Meanwhile, the anointing is only a symbol of sanctification and joy.

\section{CONCLUSION}

First, by understanding that the words "asthenei" and "kamnonta" are spiritual weakness (faith) not physical weakness / pain, there is no reason to say that the condition of the sick person referred to by James is dying. Therefore, there is no reason to establish the doctrine of the sacrament of "extreme anointing" (final anointing) as understood by the Catholic church in the text of James 5:14.

Second, since the word sick, both the word "asthenei" and the word

on the Letter from James, (New York: United Bible Societies, 1997), PC Bible Study V5; Douglas J. Moo, "James: An Introduction and Commentary" in "Tyndale New Testament Commentaries Volume 16", (USA: Inter-Varsity Press, 2015), 38. 
"kamnanto" in the context of James 5: 1415 refers to spiritual weakness (faith), not physical weakness / disease, this confirms that the anointing with oil referred to by James not related to physical healing of the disease.

Third, the contextual emphasis of James 5: 13-18 is prayer, not the anointing. This shows that when believers (without exception) experience "pain" (spiritual weakness / faith) due to the stress of suffering, the only best attitude in such a situation is prayer.

Fourth, the mandatory pastoral ministry in James 5:14 deals with "praying for" the "sick" (spiritually weak) congregation, not anointing. Then it is appropriate to call on elders to deal with that spiritual weakness. If the anointing was meant by James for physical healing, then the elders do not have to come to do the anointing, it could be done by the sick person himself or someone else.

Fifth, the anointing in James 5:14 is still in the context and understanding of Jewish culture. This means that it is the tradition (culture) of the Jews, not the culture of the Gentiles, therefore it must be understood from the perspective of the Jews. This emphasized that anointing should not be recommended for Gentiles.

Sixth, "sick" (spiritually weak / faith) in the context of James 5:14, does not indicate that the person has fallen into sin, but rather indicates that the person is discouraged or discouraged because of the pressure of suffering he is experiencing. Remember that spiritually weak people are more likely to fall into sin.

\section{REFERENCES}

[1] "Catechismo della Chiesa Cattolica" translated by Harry Susanto, $\mathrm{Sj}$, "Copendium of the Catechism of the Catholic Church". Yogyakarta: Kanasius, 2013.

[2] Sujoko, Albertus, The Practice of the Sacrament of Conversion in the Catholic Church: Historical, Dogmatic, and Pastoral Overview. Yogyakarta: Kanasius, 2008

[3] Macfarquhar, Colin, \& Bell, Andrew, The Encyclopedia Britannica a Dictionary of Arts, Sciences, and General Litterature: VI. Scotland: Charles Black, 1974.

[4] Toma, William, The Mystery of the Church. Syriac Critical Edition and Translation of the Rite of the Consecration of the Altar with Oil and the Chapter 'On the Consecration of the Church' from the 'Book of the Seven Causes of the Mysteries of the 
Journal Kerugma

E-ISSN: 2622-1039

P-ISSN: 2621-8038

Church. Doctoral Dissertation of Patriarch Timothy II (1318-1332) at the Eastern

Pontifical Institution in Rome, 2007.

[4] Herbermann, Charles, Catholic

Encyclopedia - East Syrian Rite. New

York: Robert Appleton Company, 1913.

[5] Gross, Jeffrey, et al, Introduction to

Ecumenism. New York: Paulist Press, 1938.

[6] Moo, Douglas A, Tyndale New

Testament Commentaries: James.

[7] Major, Joseph B, The Epistle of St.

James: The Greek Text With Introduction

Notes and Comments - Edition II. London:

Macmillan \& CO, 1897.

[8] The "Lutheran Service Book: Pastoral Care Company" was written by "The Commison on Worship of The Lutheran Church-Missouri Synod”. Missouri:

Concordia Publishing House, 2007.

[9] Aritonang, Jan S, Various Schools in and around the Church. Jakarta: BPK Gunung Mulia, 2008.

[10] Livingstone, Elizabeth A, The Oxford Dictionary of the Christian Church -
Unction. United States: Oxford University Press, 2005.

[11] Bird, George, Hints For The Revival of Scriptural Principles. London: Whittaker and Company, 1842.

[12] "The Book of Common Prayer". New York: Church Publishing Incorporated, 1979.

[13] Essien, Bassey B, How To Let Christ Be Formed In You. Bloomington IN, United: Xlibris Corporation, 2011.

[14] Elwell, Walter A, Evangilical Dictionary of Theology. Grand Rapids: Baker Academic, 2011.

[15] Duffield, Guy P, et al, Foundations of Pentecostal Theology. Los Angeles: Foursquare Media, 1983.

[16] Downing, W. R, Prayer and Anointing with Oil An Examination of James 5: 13-15. Morgan Hill: PIRS Publication, 2012.

[17] Wimber, John, \& Springer, Kevin, Power Evangelism. San Francisco: Harper and Row Publishers, 1986.

[18] Conner, Kevin J. \& Malmin, Ken, Hermeneutics - A Textbook On How to 
Journal Kerugma

E-ISSN: 2622-1039

P-ISSN: 2621-8038

Interpret the Bible. Malang: Gandum Mas,

s/dun/james-5.html on May 17, 2020. 2004.

[19] Saparman, Bible Study - Methods and Examples. Yogyakarta: STII Press, 2007.

[20] Willy, I. Markus, et al, Indonesian English Dictionary. Surabaya: Arkola Surabaya, 1996.

[21] Zuck, Roy B, Basic Interpretation. USA: David C. Cook, 1991.

[22] Grassmick, John D, Principles and Practice of Greek Exegesis. Yogyakarta: STTII, 2015.

[23] Cox, Alan D, Hermeneutic Principles, Bible Word V4.

[24] Henrichsen, Walter A, Understand - A Straightforward Approach to Interpreting the Bible. USA: NAVPRESS, 1976.

[25] Friberg, Timothy, et al, Analytical lexicon of the Greek New Testament. Grand Rapids: Baker Books - Baker's Greek New Testament Library, 2000.

[26] Dunagan, Mark, Commentary on the Bible - James 5:16. Accessed onhttps://www.studylight.org/commentarie [27] Vine, W. E, Vine's Complete Wxpository Dictionary of Old and New Testament. London: Thomas Nelson Publishers, 1996.

[28] Burdick, Donald W, James. In the book "Hebrews-Revelation" Volume 12 of "The Expositor's Bible Commentary 12 Volume". Edited by Frank E. Gaebelein and JD Douglas. Grand Rapids: Zondervan Publishing House, 1981.

[29] Moulton, et al, Vocabulary of the Greek New Testament (VGNT). London: Hodder and Stoughton, 1924-1930.

[30] Wallace, Daniel B, The Basics of New Testament Syntax: An Intermediate Greek Grammar. Grand Rapids: Zondervan Publishing, 2009.

[31] Wheeler, Dale M, Wheeler's Greek Syntax Notes. PC Bible Study V5.

[31] The Indonesian Simplified Translation of the Bible 2.4 (TSI). "

[32] Bible God's Word Translation.

[33] Complete Jewish Bible (CJB). 
Journal Kerugma

E-ISSN: 2622-1039

P-ISSN: 2621-8038

[34] Forrester, E. J, An Exegesis of James

5: $14-20$.

[35] Major, Joseph B, The Epistle of St. James the Greek Text With Introduction Notes And Comments (Second Edition). London: Macmillan and Co., 1879.

[36] Morgan, Robert J. James 5:14: Should Anoint the Sick With Oil ?. Accessed onhttps://www.robertjmorgan.com/uncateg orized/james-514-should-we-anoint-thesick-with-oil/ accessed on 15 May 2020.

[37] Constable, Thomas, Notes on James. 2007 edition pdf.

[38] Blue, J. Ronald, James. In "The Bible Knowledge Commentary New Testament: An Exposition of the Scriptures". Edited by John F. Walvoord and Roy B. Zuck. USA: David C. Cook, 1985.

[39] Moo, Douglas J, James: An Introduction and Commentary. In Tyndale New Testament Commentaries Volume 16. USA: Inter-Varsity Press, 2015.

[40] Burdick, Donald W, et al, James. In "The Expositor's Bible Commentary (Vol 12) Hebrews through Revelation. Grand Rapids: Zondervan, 1982.
[41] Robertson, A. Thomas, Word Pictures in the New Testament. Grand Rapids: Christian Classics Ethereal Library, 18631934.

[42] Loh, IJ, \& Hatton, HA, A Handbook on the Letter from James. New York: United Bible Societies, 1997. 